\title{
DPPA3 Gene
}

National Cancer Institute

\section{Source}

National Cancer Institute. DPPA3 Gene. NCI Thesaurus. Code C95052.

This gene plays a role in stem cell biology. 